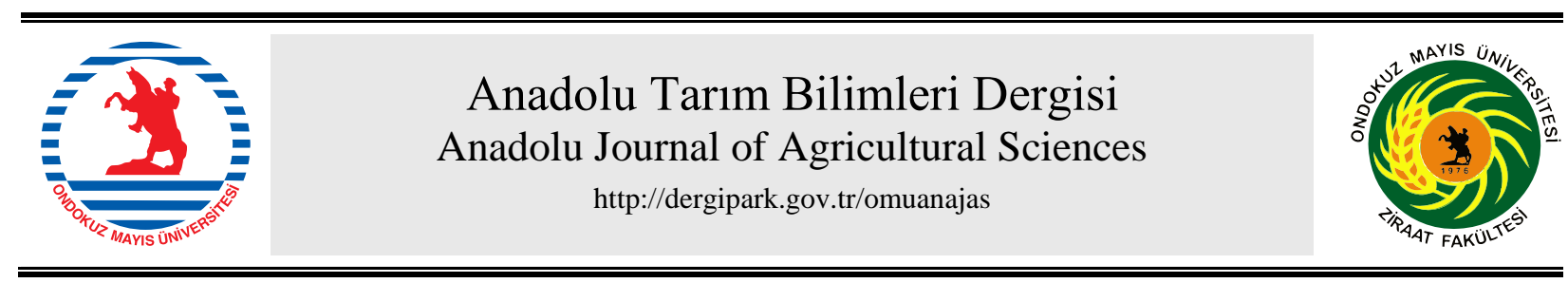

Araştırma/Research

Anadolu Tarım Bilim. Derg./Anadolu J Agr Sci, 35 (2020)

ISSN: 1308-8750 (Print) 1308-8769 (Online)

doi: 10.7161/omuanajas.697458

\title{
Biyokömür ve solarizasyon uygulamalarının bazı toprak fiziksel özellikler üzerine etkileri
}

\author{
๑Pelin Alaboz ${ }^{\mathrm{a}^{*}}$, ๑Hasan Öz ${ }^{\mathrm{b}}$ \\ ${ }^{a}$ Isparta Uygulamalı Bilimler Üniversitesi, Ziraat Fakültesi, Toprak Bilimi ve Bitki Besleme Bölümü, Doğu kampüsü, Isparta, Türkiye \\ ${ }^{b}$ Isparta Uygulamalı Bilimler Üniversitesi, Ziraat Fakültesi, Tarımsal Yapılar ve Sulama Bölümü, Doğu kampüsü, Isparta, Türkiye
}

*Sorumlu yazar/corresponding author: pelinalaboz@isparta.edu.tr

Geliş/Received 03/03/2020 Kabul/Accepted 26/03/2020

\begin{abstract}
ÖZET
Son yıllarda oldukça dikkat çeken biyokömür'ün toprak düzenleyici olarak etkinliği yaygın bir şekilde araştırılmaktadır. Bu çalışmada sera koşullarında biyokömür uygulamalarının [0(B0), 0.15(B1) ton da da $^{-1}$ farklı solarizasyon örtü materyalleri [polietilen (PE), balonlu polietilen (BPE)] ile birlikte bazı toprak fiziksel özellikler üzerine etkisi araştırılmıştır. Biyokömür uygulamaları ile toprakların penetrasyon direnci $1 \mathrm{MPa}$ 'dan $0.89 \mathrm{MPa}$ seviyelerine kadar düşmüştür. Uygulamaların hacim ağırlığı üzerine etkileri penetrasyon direnci ile benzerlik göstermiş fakat istatistiksel olarak önemli bulunmamıştır. Uygulamalardaki değişimlere bağlı olarak toprakların agregasyon oranı \% 78.48-87.06 arasında belirlenmiştir. BPE örtü materyali ve B1 uygulamaları ile en yüksek agregasyon oranı elde edilmiştir. Biyokömür uygulamalarıyla yarayışlı su içeriği yaklaşık \% 1 seviyesinde istatistiksel olarak önemli $(\mathrm{P}<0.01)$ artış göstermiştir. Çalışma sonucunda agregasyon oranı üzerine BPE örtü materyali etkili olarak bulunmuştur. Ayrıca biyokömür uygulamaları ile penetrasyon direncinde azalış, yarayışlı su içeriğinde artışlar belirlenmiştir.
\end{abstract}

\section{Effects of Biochar and Solarization Applications on Some Soil Physical Properties}

Anahtar Sözcükler: Solarizasyon Biyokömür Penetrasyon direnci Agregasyon Yarayışlı su içeriği

\begin{abstract}
The effectiveness of biochar, which has attracted attention in recent years, is widely researched as a soil conditioner. In this study, the effects of biochar applications [0 (B0), 0.15 (B1) tons $\mathrm{da}^{-1}$ ] on different soil physical properties together with different solarization cover materials [polyethylene (PE), bubble polyethylene (BPE)] were investigated in greenhouse conditions. Soil penetration resistance has decreased from $1 \mathrm{MPa}$ to $0.89 \mathrm{MPa}$ levels with Biochar applications. The effects of applications on bulk density were similar to penetration resistance but were not found statistically significant., The aggregation rate of the soils was determined between 78.48-87.06 \% depending on the changes in the applications. The highest aggregation rate was obtained from BPE covering material and B1 applications. The available water content showed thet there was a statistically significant $(\mathrm{P}<0.05)$ increase in the level of about $1 \%$ with biochar applications. As a result of the study, BPE cover material was found effective on the aggregation rate. In addition, penetration resistance decreased, While, available water content increased with biochar application.
\end{abstract}

Keywords: Solarization Biochar Penetration resistance Aggregation Available water content 


\section{Giriş}

Bitki gelişme ortamı olan toprağın sahip olduğu verimlilik kabiliyeti yalnızca besin elementi içeriğiyle değil fiziksel özellikleriyle de yakından ilgilidir. Bitkisel üretimde optimum verim için gerekli olan kimyasal şartların yanında, olumsuz fiziksel özellikler, verim ve verim öğelerini negatif yönde etkilemektedir. Toprak fiziksel koşullarında giderek artan zayıflamalar toprakta degradasyona neden olarak arazi kullanımı ve ürün yönetimini etkilemektedir (Chan ve ark., 2003). Toprakta fiziksel koşulların iyileştirilmesinde organik ya da mineral toprak düzenleyicilerin kullanılması yaygın bir uygulamadır. Son yıllarda, organik materyallerin yüksek sıcaklıklarda $\left(300-1000^{\circ} \mathrm{C}\right)$ pirolizi sonucunda elde edilen biyokömür'ün toprak fiziksel özelliklerinin iyileştirilmesinde düzenleyici olarak kullanılması birçok araştırıcı tarafindan incelenmiştir (Busscher ve ark., 2010; Mankasingh ve ark. 2011; Karhu ve ark., 2011 Novak ve ark., 2012; Alaboz ve Işıldar, 2018). Toprakta karbon (C) kaynağ 1 olarak düşünülen biyokömür'ün gözenekliliği yüksek seviyelerdedir (Verheijen ve ark., 2010).

Toprağa uygulanan materyallerin parçalanma ayrışmalarında toprak sıcaklığı oldukça önemli bir faktördür (Dündar, 1987). Toprak solarizasyonu, güneș enerjisi yardımıyla şeffaf bir örtüyle kaplanmış nemli toprağın 1sitılması ve toprak kökenli zararlıların yok edilmesi amacıyla kullanılan bir yöntemdir. $\mathrm{Bu}$ uygulamalarda, farklı örtü materyallerinin kullanılmasıyla toprak sicaklığında önemli değişimler görülmektedir (Doğan, 1995; Raj ve Bhardwaj, 2000; Patel ve ark., 2005, Öz ve ark., 2017). Solarizasyon uygulamalarının besin element içerikleri (Koçar ve ark., 2006; Sofi ve ark.,2014) ve agregasyon üzerine etkileri olumludur (Reddy, 2011). Solarizasyon toprak sicaklığını değiştirmekte olup (Öz, 2018) bu değişim bazı toprak fiziksel, kimyasal ve biyolojik özellikleri etkilemektedir. Toprak sıcaklığının kök gelişimi üzerinde önemli etkisi dolaylı olarak toprakta agregasyon üzerinde de olumlu etki göstermektedir (Çepel, 1988). Solarizasyonla ilgili yapılan çalışmalarda genellikle toprağın kimyasal ve biyolojik özellikleri üzerine etkiler incelenmiștir (Mauromicale ve ark., 2005; Scopa ve Dumontet, 2007; Seman Varner ve ark., 2008; Öz ve ark., 2016; Gupta ve ark., 2017).

Degradasyona uğramış topraklarda fiziksel koşulların iyileştirilmesi toprak verimliliği ve besin elementlerinin alınabilirliği yönünden oldukça önemlidir. Bu sorunun çözülmesinde yeni bir yaklaşım olan biyokömür'ün kullanılabilirliği günümüzde araştırma aşamasındadır. Bu çalışmanın temel amacı, biyokömür ve solarizasyon uygulamalarının bazı toprak fiziksel özellikleri (hacim ağırlığı, penetrasyon direnci, agregasyon oranı, yarayışlı su içeriği) üzerine etkisinin araştırılmasıdır.

\section{Materyal ve Yöntem}

\section{1 Çalışma alanı ve toprak özellikleri}

$\mathrm{Bu}$ çalışma, Isparta Uygulamalı Bilimler Üniversitesi Ziraat Fakültesi Tarımsal Araștırma ve Uygulama Çiftliğinde bulunan $\left(37^{\circ} 50^{\prime} \mathrm{N} ; 30^{\circ} 32^{\prime} \mathrm{E}\right) 6$ $\mathrm{m}$ genişliğinde, $15 \mathrm{~m}$ uzunluğunda $90 \mathrm{~m}^{2}$ taban alanına sahip, yay çatıll, çelik konstrüksiyonlu serada yürütülmüştür (Şekil 1). Çiftlik toprakları genellikle hafif eğimli, aluviyal yelpaze üzerinde yüksek tepe ve sırtlarla çevrili bir çukurluk üzerinde yer almaktadır (Akgül ve Başayiğit, 2005). Toprak nem rejimi xeric, toprak sıcaklık rejimi ise mesic'dir (Akgül ve ark., 2002).

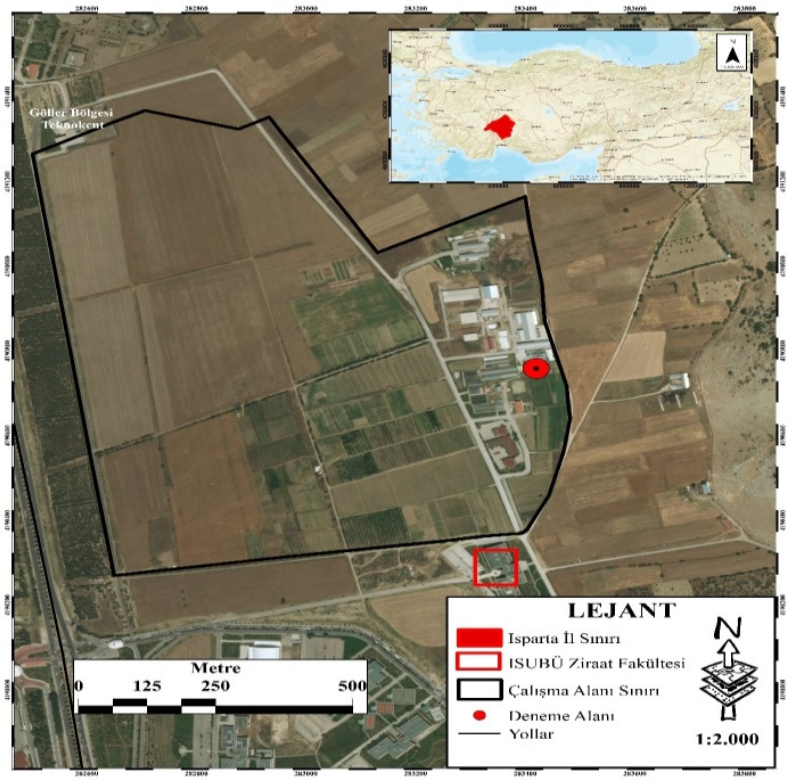

Şekil 1. Çalışma alanı

Figure 1. Study area

Sera içerisinde bulunan topraklar ince bünye grubunda ( \%46 kil, \% 35 silt, \% 19 kum) killi tekstür sinıfindadır. Doran ve Jones (1996)'a göre tuzsuz sinıfinda olan toprakların, Kacar, (2009); Hazelton ve Murphy, (2016)'ye göre organik madde içerikleri düşük (\% 1.76), pH's1 hafif alkalindir. Toprakların tarla kapasitesi \% $27\left(\mathrm{~g} \mathrm{~g}^{-1}\right)$ solma noktası ise \% $15\left(\mathrm{~g} \mathrm{~g}^{-}\right.$ ${ }^{1}$ )'dir.

\subsection{Denemenin kurulması ve yürütülmesi}

Solarizasyon uygulaması gerçekleştirilecek parseller, $2 \times 2 \mathrm{~m}$ boyutlarında tesadüf parsellerinde bölünmüş parseller deneme desenine göre planlanmıştır. Deneme, 4 adet uygulama parselinden oluşmuştur. Uygulamada 2 farklı polietilen örtü malzemesi ve biyokömür (B) uygulaması test edilmiştir. Birinci örtü malzemesi; polietilen (PE) üreticiler tarafindan sıklıkla 
kullanılan solarizasyon örtü malzemesi $0.03 \mathrm{~mm}$ kalınlığında, ikinci örtü malzemesi ise ambalaj uygulamalarında kullanılan içi hava dolu baloncuğa sahip malzemedir (BPE). Baloncuk çapı $30 \mathrm{~mm}$ ve baloncuk yüksekliği 12.5 mm'dir. Deneme, PE, BPE, $\mathrm{PE}+$ Biochar, $\mathrm{BPE}+\mathrm{Biochar}$ uygulamalarından oluşmuştur.

Uygulamada kullanılan Biyokömür kavak talaşından, $400{ }^{\circ} \mathrm{C}$ piroliz sıcaklığında 5 saat sürede üretilmiştir. Elde edilen biyokömür 2 mm'lik elekten elenerek kaba parçalar uzaklaştırılmıştır. Denemede biyokömür, el yardımıyla 0.15 ton dekar ${ }^{-1}$ (B1) olacak şekilde parsel yüzeyini ince bir örtü biçiminde serilmiştir. Bir aylık solarizasyon uygulamasından sonra örtü malzemeleri kaldırılmıştır. Standart yetiştiricilik yapılmas1 durumunda biyokömür ve solarizasyonun topraktaki etkilerinin incelenmesi adına Marul bitkisi yetiştirilmiştir. Bitkiler parsellere dikilmeden önce, biyokömür 0-15 cm derinlikte parsellere karıştırılmış, marul bitkisi için önerilen $110 \mathrm{~kg} \mathrm{ha}^{-1} \mathrm{~N}, 100 \mathrm{~kg} \mathrm{ha}^{-1}$ $\mathrm{P}_{2} \mathrm{O}_{5}$ ve $50 \mathrm{~kg} \mathrm{ha}^{-1} \mathrm{~K}_{2} \mathrm{O}$ taban gübrelemesi damla sulamayla uygulanmıştır. Fideleri $30 \times 20 \mathrm{~cm}$ aralıklarla (12 bitki $\mathrm{m}^{-2}$ ) dikilerek, yaklaşı 3 ay sonra hasat edilmiştir.

\subsection{Yöntem}

Toprak örneklerinin pH ve EC' leri 1:2.5 toprak - su süspansiyonunda, Eşdeğer \% $\mathrm{CaCO} 3$ içerikleri volumetrik kalsimetre yöntemiyle, organik madde içerikleri ise değiştirilmiş Walkley-Black yöntemi kullanılarak hesaplanmıştır (Soil Survey Staff, 1992; Burt, 2014). Toprakların bünye sınıfı (\% kum, silt, kil) Bouyoucos hidrometre yöntemiyle (Bouyoucos, 1954), Hacim ağırlığ 1 (HA), $100 \mathrm{~cm}^{3}$ hacmine sahip silindirler yardımıyla bozulmamış toprak örneklerinde belirlenmiştir (Blake ve Hartge, 1986). Penetrasyon direnç (PD) ölçümleri penetrologger (Eijkelkamp) kullanılarak gerçekleştirilmiştir. Penetrologger, $80 \mathrm{~cm}$ toprak derinliğine kadar her bir $\mathrm{cm}$ için $0-10 \mathrm{MPa}$ arasında ölçüm yapabilen özelliğe sahiptir. Ölçümlerde kullanilan cone, $60^{\circ}$ (NEN 5140, 1996) ve $1 \mathrm{~cm}^{2}$ taban alanı koni şeklinde uç kullanılmıştır. Toprak örneklerinin nem içerikleri, $105{ }^{\circ} \mathrm{C}$ 'de etüvde sabit ağırlığa gelinceye kadar kurutularak gravimetrik olarak hesaplanmıştır (Burt, 2014). Toprakların 0.33 ve 15 bar tansiyonlarda tutulan nem içerikleri bozulmuş örneklerde seramik tablalı pF seti (U.S.A, Soil Moisture Equipment Corp.) yardımıyla belirlenmiştir (Demiralay, 1993). Yarayışlı su içerikleri (YSİ) 0.33 ve 15 bar nem içeriklerinin farklarından hesaplanmıştır. Agregasyon yüzdesi toplam silt+kil ve bağlanmamış silt + kil belirlemeleri yardımıyla hesaplanmıştır (US Salinity Laboratory Staff., 1954). Penetrasyon direnci, nem içeriğine bağlı olarak önemli bir değişim sergilemektedir. Toprak örneklerinin nem içeriklerindeki farklılıklar penetrasyon direncinin değerlendirilmesinde yanıltıcı etki göstermektedir. $\mathrm{Bu}$ yüzden penetrasyon direnci okumalarında toprakların nem içeriklerinin sabit olması beklenilmekte ancak arazi şartlarında bunun gerçekleşmesi oldukça zordur. Standart bir nem içeriğine bağlı penetrasyon direnci değişimini belirleyebilmek için Alaboz (2019) tarafindan ağır bünyeli topraklar için belirtilen denklem kullanılmıştır (Eşitlik 1). Standart nem dönüşümlerinde toprağın tarla kapasitesi seviyesi dikkate alınmıştır.

$\mathrm{PR}=\mathrm{PRx} e^{[(\mathrm{x}-0.27) / 0.126]}$

PR: Düzeltilmiş penetrasyon direnci ( $\mathrm{MPa})$

PRx: Arazide ölçülen penetrasyon direnci (MPa),

$\mathrm{X}$ : Arazide ölçüm yapılan toprağın nem içeriği $\left(\mathrm{kg} \mathrm{kg}^{-1}\right)$ $/\left(\mathrm{cm}^{3} \mathrm{~cm}^{-3}\right)$

0.27: standardizasyon için seçilen TK'daki nem içeriği $\left(0.27 \mathrm{~kg} \mathrm{~kg}^{-1}\right) /\left(\mathrm{cm}^{3} \mathrm{~cm}^{-3}\right)$

Verilerin varyans analizi (ANOVA), çoklu karşılaştırma testlerinden TUKEY seçilerek Minitap paket programı yardımıyla değerlendirilmiştir.

\section{Bulgular ve Tartışma}

\subsection{Hacim ağırlı̆̆g ve penetrasyon direnci}

Solarizasyon ve biyokömür uygulamalarının toprak hacim ağırlığı ve penetrasyon direncine etkilerini gösteren varyans analiz tablosu Çizelge 1'de belirtilmiştir. Toprakların PD değerleri $0.89-1.08 \mathrm{MPa}$, HA ise 1.27-1.33 $\mathrm{g} \mathrm{cm}^{-3}$ arasında değişim göstermiştir. Biyokömür uygulamalarındaki değişim PD üzerinde istatistik olarak önemli seviyede belirlenmiş, $(\mathrm{P}<0.05)$ ana etkilerden solarizasyon ve biyokömür $\mathrm{x}$ solarizasyon interaksiyonu istatistiksel olarak önemli bulunmamıştır. Hacim ağırlığı üzerine uygulamaların, hem ana etkileri hem de interaksiyonlarında önemli seviyelerde bir değişim gözlenmemiştir.

Çizelge 1. Biyokömür ve solarizasyon uygulamalarının hacim ağırlığı ve penetrasyon direnci üzerine etkisi

Table 1. The effect of biochar and solarization applications on bulk density and penetration resistance

\begin{tabular}{lccc}
\hline Biyokömür & Solarizasyon & $\begin{array}{c}\text { PD } \\
(\mathrm{MPa})\end{array}$ & $\begin{array}{c}\mathrm{HA} \\
\left(\mathrm{g} \mathrm{cm}^{-3}\right)\end{array}$ \\
\hline \multirow{2}{*}{$\mathrm{B} 0$} & $\mathrm{PE}$ & 1.08 & 1.33 \\
& $\mathrm{BPE}$ & 0.93 & 1.32 \\
\hline \multirow{2}{*}{$\mathrm{B} 1$} & $\mathrm{PE}$ & 0.90 & 1.32 \\
& $\mathrm{BPE}$ & 0.89 & 1.27 \\
\hline \multicolumn{2}{c}{ Varyasyon Kaynağ1 } & $\mathrm{P}$ & $\mathrm{P}$ \\
\hline Solarizasyon & 0.213 & 0.452 \\
Biyokömür & 0.045 & 0.518 \\
Solarizasyon*Biyokömür & 0.144 & 0.621 \\
Varyasyon Kaynağ1 & $\mathrm{F}$ & $\mathrm{F}$ \\
Solarizasyon & 1.83 & 0.63 \\
Biyokömür & 5.62 & 0.46 \\
Solarizasyon*Biyokömür & 2.63 & 0.26 \\
\hline
\end{tabular}

B0:kontrol B1:0.15ton/da biyokömür, PE:polietilen, BPE: balonlu polietilen, PD:penetrasyon direnci, HA:Hacim ağırlığı 
Biyokömür ve solarizasyon materyalinin ana etkileri Şekil 2'de gösterilmiştir. Solarizasyon materyalinin toprak penetrasyon direnci ve hacim ağırlığı üzerinde istatistiksel önemli bir etkisi belirlenemez iken 0.15 ton

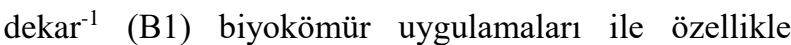
penetrasyon direncinde yaklaşı \% 11'lik bir azalma görülmüştür. Penetrasyon direncindeki bu azalma HA üzerinde de etkili olmuş (Şekil 2) fakat istatistiksel olarak önemli bir değişim belirlenememiştir. Sıkışmayla birlikte penetrasyon direncinin artması, buna bağl olarak hacim ağırlığındaki artışlar birçok araştırıcı tarafindan bildirilmiştir (Şeker ve Işıldar, 2000; Aksakal ve Öztaş, 2010; Junior ve ark., 2014; Silva ve ark., 2016). Biyokömür uygulamalarıyla toprak penetrasyon direnci azalmaktadır (Negiş ve ark., 2019). Biyokömür'ün gözenekliliğinin yüksek olması topraktaki gözenekliliğin artışına neden olmaktadır. Toprak gözenekliliğinde meydana gelen azalış, PD'de artı̧̧lara yol açtığı (Şeker ve Işılldar, 2000) gibi gözeneklilikteki artış hem PD'de hem de HA'da azalışlara neden olmaktadır. Ayrıca topraklara organik materyal uygulamaları hacim ağırlığı ve penetrasyon dirençlerini azaltmaktadır (Celik ve ark., 2010; Müjdeci ve ark., 2017).

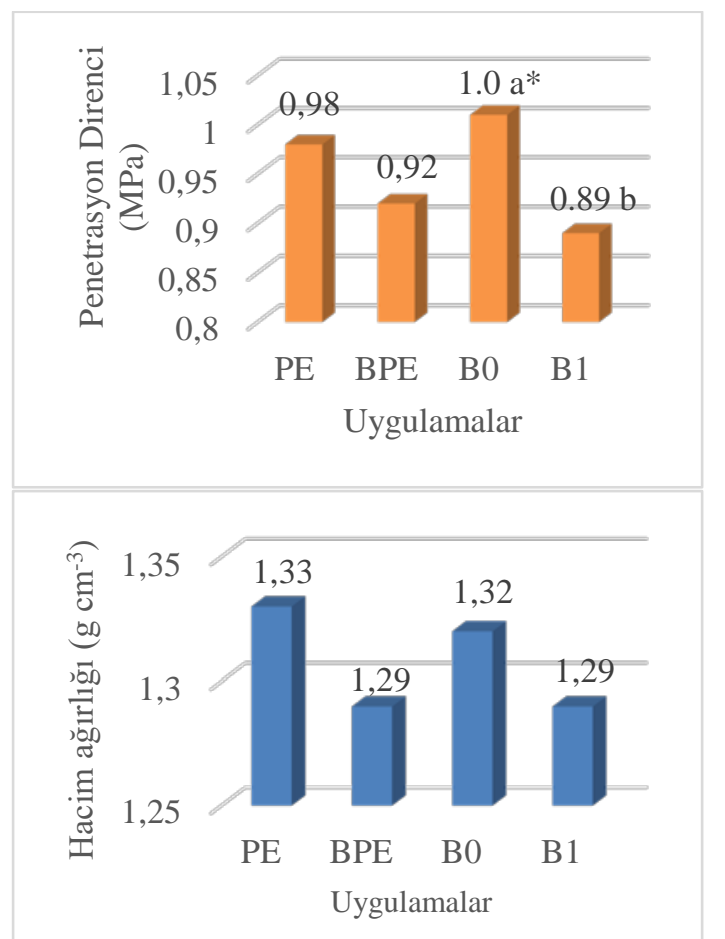

B0:kontrol B1:0.15ton/da biyokömür, PE:polietilen, BPE: balonlu polietilen, *Küçük harfler biyokömür uygulamalarının etkileri

Şekil 2. Uygulamaların hacim ağırlığı ve penetrasyon direnci üzerine etkileri

Figure 2. Effects of applications on bulk density and penetration resistance

\subsection{Agregasyon oranı ve yarayışlı su kapasitesi}

Biyokömür ve solarizasyon uygulamalarının agregasyon oranı ve yarayışlı su içeriği üzerindeki değişimleri Çizelge 2'de belirtilmiştir. Agregasyon oranı üzerine uygulamaların ana etkileri istatistik olarak önemli seviyede $(\mathrm{P}<0.05)$ değişim gösterirken interaksiyonları önemsiz bulunmuştur. Yarayışlı su içeriğinde ise sadece biyokömür uygulamalarının etkisi önemli seviyede $(\mathrm{P}<0.05)$ değişim göstermiştir. Toprakların agregasyon oranı \% 78.48-87.06, yarayışlı su içeriği \% 12.05-12.90 aralıklarında değişim gösterirken uygulamaların ana etkileri Şekil 3'de belirtilmiştir.

Çizelge 2. Biyokömür ve solarizasyon uygulamalarının agregasyon oranı ve yarayışlı su üzerine etkisi

Table 2. The effect of biochar and solarization applications on aggregation rate and useful water

\begin{tabular}{lccc}
\hline Biyokömür & Solarizasyon & $\begin{array}{c}\text { Agregasyon } \\
\text { oran1 (\%) }\end{array}$ & $\begin{array}{c}\text { Yarayışl1 } \\
\text { su içeriği } \\
(\%)\end{array}$ \\
\hline \multirow{2}{*}{ B0 } & $\mathrm{PE}$ & 78.48 & 12.05 \\
& $\mathrm{BPE}$ & 82.67 & 12.09 \\
\hline \multirow{2}{*}{$\mathrm{B} 1$} & $\mathrm{PE}$ & 80.85 & 12.60 \\
& $\mathrm{BPE}$ & 87.06 & 12.90 \\
\hline \multicolumn{2}{c}{ Varyasyon Kaynağ1 } & $\mathrm{P}$ & $\mathrm{P}$ \\
\hline Solarizasyon & 0.004 & 0.091 \\
Biyokömür & 0.022 & 0.001 \\
Solarizasyon*Biyokömür & 0.371 & 0.165 \\
Varyasyon Kaynağ1 & $\mathrm{F}$ & $\mathrm{F}$ \\
Solarizasyon & 25.69 & 4.93 \\
Biyokömür & 10.85 & 78.87 \\
Solarizasyon*Biyokömür & 0.97 & 2.88 \\
\hline B0:kontrol B1:0.15ton/da biyokömür, PE:polietilen, BPE: balonlu polietilen
\end{tabular}

Solarizasyon uygulamalarında en yüksek agregasyon oranı BPE'de (\% 84.87) belirlenmiştir. BPE uygulamasıyla agregasyonda yaklaşık $\% \quad 5$ artış görülmektedir. BPE, PE uygulamalarına göre toprak sıcaklığını daha fazla arttırmaktadır. Baloncuklu PE malzemesinin içerisinde bulunan hava sayesinde, güneş 1şınlarıyla isınan topraktan havaya 1sı geçişi azalarak tek kat PE örtü malzemesine göre daha fazla 1sı korunumu sağlanmaktadır (Öz ve ark., 2017; Öz, 2018). Toprak sıcaklığının artması mikrobiyal aktiviteyi arttırarak parçalanma ve ayrışma hızını arttırmaktadır (Ekberli ve Dengiz, 2016). Parçalanma sonucu ortaya çıkan hümik maddeler, moleküller arasında flokülasyona neden olarak agregasyonu arttırmaktadır (Yılmaz ve Alagöz, 2000). Ayrıca mikroorganizmaların metabolik ürünleri olan organik salgıların yapıştırıcı etkileri de agregasyon üzerinde etkilidir (Sağlam ve ark., 1993). Dolayısıyla BPE'de sicaklığın daha fazla artması agregatlaşma üzerinde pozitif etki göstermiştir. Biyokömür uygulamasıyla ise agregasyonda $\% 3$ seviyelerinde artı̧̧ belirlenmiştir. Farklı kaynaktan elde edilen biyokömür uygulamalarının agregasyon üzerinde artışa yol açtığı 
geçmiş araştırmalarda da rapor edilmiştir (Liu ve ark., 2012; Sun and Lu, 2014; Alaboz ve Iş1ldar, 2018). Benzer şekilde biyokömür uygulaması sonucu organik madde içeriği ve agregasyonda artışlar olduğu bilinmektedir (Abdulwahhab ve Şeker, 2019).

Farklı solarizasyon materyali uygulamalarının YSI üzerine etkisi önemli bir değişim (\% 12.5, 12.32) göstermemiştir (Şekil 3). Biyokömür uygulamaları ise yarayışlı su içeriğinde yaklaşık \%1'lik bir artış sağlamıştır.
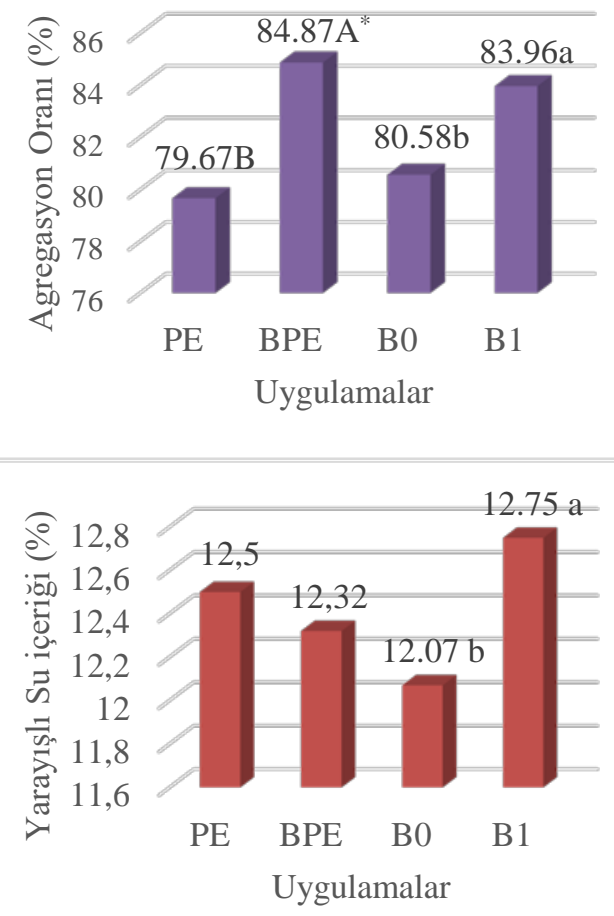

B0:kontrol B1:0.15ton/da biyokömür, PE:polietilen, BPE: balonlu polietilen , * büyük harfler solarizasyon materyalinin etkisi, küçük harfler biyokömür uygulamalarının etkileri

Şekil 3. Uygulamaların agregasyon oranı ve yarayışlı su içeriği üzerine etkileri

Figure 3. Effects of applications on aggregation rate and available water content

Biyokömür uygulama miktarının yüksek olması ile su tutma kapasitesinin daha fazla artacağı düşünülmekte, ancak doğrusal bir orant1 kurulamamaktadır. Nitekim geçmiş araştırmalarda uygulamalar genellikle daha yüksek seviyelerdedir (Dovnie ve ark., 2009; Devereux ve ark., 2012; Alaboz ve Ișıldar, 2018). Ancak biyokömür'ün özgül ağırlığının çok düşük olması ve elde edilebilirliğinin zahmetli olması nedeniyle bu çalışmada daha düşük seviyelerde biyokömür uygulanmasının denenmesi benzer YSİ artışlarının elde edilememesinin bir sebebidir. Toprakta su, gözeneklerde tutulmakta olup özgül yüzey arttıkça toprakların su tutma potansiyelleri artmaktadır. Özgül yüzeyi yüksek olan biyokömür (Dovnie ve ark., 2009;
Lehmann ve Joseph, 2015), porozite, su içeriği (Dovnie ve ark., 2009) ortalama gözenek çapı (Devereux ve ark., 2012) gibi özellikler üzerinde etkilidir. Dolayısıyla tutulabilir su miktarı artmaktadır. Alaboz ve ark. (2017), $\% 2$ biyokömür uygulamaları ile YSİ'nin yaklaşık \% 4 seviyelerinde artış gösterdiği bildirilmiştir.

\section{Sonuç}

$\mathrm{Bu}$ çalışmada; farklı solarizasyon örtü materyallerinin biyokömür uygulamalarıyla birlikte bazı toprak fiziksel özellikleri üzerine etkisi incelenmiştir. Solarizasyon materyallerinin etkisi sadece agregasyon oranında etkili olup agregasyonun artışı BPE örtü materyali ile daha yüksek bulunmuştur. Solarizasyonda kullanılan materyallerin; toprakların katı, sivı, gaz formları ile ilgili fiziksel özellikler (HA, PD) üzerine etkisi belirlenememiş, ancak kimyasal ve biyolojik süreçlerden de etkilenen toprak özellikleri (agregasyon, YSI) üzerine etkisi önemli bulunmuştur. Biyokömür uygulamaları ile hacim ağırlığı ve penetrasyon direncinde azalışlar belirlenirken agregasyonda $\% 5$ ve YSI'de ise \% 1'lik önemli seviyede artışlar gözlenmiştir. Biyokömür, farklı organik materyallerden elde edilmektedir. Dolayısıyla farklı özellikler göstermekte olup fiziksel parametreler üzerinde de etkileri değişim göstermektedir. $\mathrm{Bu}$ çalışmada biyokömür uygulamasiyla su tutma ve agregasyonda artışlar belirlenmiştir. Fakat optimum verim için hangi seviyede biyokömür uygulanması gerekliliğinin bilinmesi oldukça önemlidir. Ayrıca hem zararlılarla mücadele hem de biyokömür'ün etkinliğinin arttırılması adına farklı solarizasyon örtü materyallerinin ileride kurgulanacak farklı araştırmalar ile incelenmesi tarafımızca önerilmektedir.

\section{Kaynaklar}

Abdulwahhab, Q.R., Şeker, C., 2019. Effect of biochar applications on soil aggregation status. International Soil Congress 2019, 17-19 June Ankara, Turkey.

Akgül, M., Başayiğit. L., Uçar. Y., 2002. Atabey ovası topraklarının genel özellikleri ve sinıflandırılması. Süleyman Demirel Üniversitesi Fen Bilimleri Enstitüsü Dergisi, 6(1): 1-13.

Akgül, M., Başyiğit, L., 2005. Süleyman Demirel üniversitesi çiftlik arazisinin detaylı toprak etüdü ve haritalanmas1. Süleyman Demirel Üniversitesi Fen Bilimleri Enstitüsü Dergisi, 9(3): 1-10.

Aksakal, E.L., Öztaş, T., 2010. Changes in distribution patterns of soil penetration resistance within a silage-corn field following the use of heavy harvesting equipments. Turkish Journal of Agriculture and Forestry, 34: 173-179. doi.org/10. 3906/tar-0906-189.

Alaboz, P., Coskan, A., Isildar, A.A., 2017. Effects of saw-dust biochar on some soil moisture constants. 
Fresenıus Environmental Bulletın, 26(6): 40334038.

Alaboz, P., Iş̧1dar, A. A., 2018. Elma ve gül posası biyokömürlarının kumlu toprağın bazı fiziksel özellikleri üzerine etkileri. Toprak Bilimi ve Bitki Besleme Dergisi, 6(2): 67-72.

Alaboz, P., 2019. Bazı toprak nem sabitelerinin penetrasyon direnci ölçümleriyle belirlenebilmesi için tahmin modellerinin geliştirilmesi. Doktora Tezi. Süleyman Demirel Üniversitesi Fen Bilimleri Enstitüsü, 142s, Isparta.

Blake, G.R., Hartge, K.H., 1986. Bulk density. p. 363382. In A. Klute (ed.) Methods of soil analysis. Part 1. Physical and mineralogical methods. 2nded. Agron. Monogr. 9. ASA and SSSA, Madison, WI.

Bouyoucos, G.J., 1962.Hydrometer method improved for making particle size analyses of soils. Agron. J., 54: 464-465.

Burt. R. (Ed.)., 2014. Soil survey field and laboratory methods manual. United States Department of Agriculture. Natural Resources Conservation Service. National Soil Survey Center. Natural Resources Conservation Service. Kellog Soil Survey Laboratory.

Busscher, W.J., Novak, J.M., Evans, D.E., Watts, D.W., Niandou, M.A.S., Ahmedna, M., 2010. Influence of pecan biochar on physical properties of a porfolk loamy sand. Soil Science, 175: 10-14. doi.org/0.1097/SS.ObOl3e3 181 cb7f46.

Celik, I., Gunal, H., Budak, M., Akpinar, C., 2010. Effects of longterm organic and mineral fertilizers on bulk density and penetration resistance in semiarid Mediterranean soil conditions, Geoderma, 160: 236-243. doi.org/10.1016/j.geoderma.2010.09.028.

Chan, K.Y., Heenan, D.P., So, H.B., 2003. Sequestration of carbon and changes in soil quality under conservation tillage on lighttextured soils in Australia: a review. Australian Journal of Experimental Agriculture, 43: 325-334. doi.org/10. 1071/EA02077.

Çepel, N., 1988. Toprak ilmi ders kitabı; orman topraklarının karakteristikleri, toprakların oluşumu, özellikleri ve ekolojik bakımdan değerlendirilmesi. İstanbul Üniversitesi Orman Fakültesi Yayınları, Yayın No: 3416, 276s, İstanbul.

Demiralay, İ., 1993. Toprak fiziksel analizleri. Ataturk Üniversitesi Ziraat Fakültesi Yayınları, 143s, Erzurum.

Deveraux, R.C., Sturrock, C.J., Mooney, S.J., 2012. The effects of biochar on soil physical properties and winter wheat growth. Earth and Environmental Science Transactions of the Royal Society of Edinburgh 103: 13-18. doi.org/10.1017/S17 5569 1012000011.

Doğan, M.N., 1995. Yerfistığında gövde çürüklüğü hastalığına karşı solarizasyon etkinliğinin araştırılması. Yüksek Lisans Tezi. Çukurova Üniversitesi Fen Bilimleri Enstitüsü, 56s, Adana.
Doran, J.W, Jones, A.J., 1996. Methods for assessing soil quality. Soil Science Society of America Special Publication 49. SSSA. Madison. WI.

Downie, A., Crosky, A., Munroe, P., 2009. Physical properties of biochar. In Lehmann J, Joseph S. (Eds.) Biochar for Environmental Management. Science and Technology, 1332s, Earthscan. London.

Dündar, M., 1987. Toprak organik maddesi ve ekolojik yönden önemi. İstanbul Üniversitesi Orman Fakültesi Dergisi, 37(1): 99-108.

Ekberli, İ., Dengiz, O., 2016. Bazı inceptisol ve entisol alt grup topraklarının fiziko-kimyasal özellikleriyle ısısal yayınım katsayısı arasındaki regresyon ilişkilerin belirlenmesi. Toprak Su Dergisi, 5(2): 110. doi.org/ 10.21657/topraksu.268957.

Gupta, S., Singh, R. P., Rautela, P., 2017. Effect of soil solarization on physio chemical properties of soil under protected cultivation. Int. J. Chem. Stud, 5: 2039-2042.

Hazelton, P., Murphy, B (Eds.)., 2016. Interpreting soil test results: What do all the numbers mean?. CSIRO publishing.

Junior, D.D.V., Biachini, A., Valadão, F.C.A., Rosa, R.P., 2014. Penetration resistance according to penetration rate, cone base size and different soil conditions. Bragantia, 73(2): 171-177. doi.org/10. 1590 /brag.2014.013.

Kacar, B., 2009. Toprak Analizleri. Nobel Yayın evi, 468s, Ankara.

Karhu, K., Mattila, T., Bergstrom, I., Regina, K., 2011. Biochar addition to agri-cultural soil increased ch4 uptake and water holding capacity results from a short-term pilot field study. Agriculture, Ecosystems \& Environment, 140: 309-313. doi.org/10.1016/ j.agee.2010.12.005.

Koçar, G., Okur, B., Şafak, S., 2006. Toprak solarizasyonunda kullanılan değişik örtü malzemelerinin toprak sıcaklığı ile bazı fiziksel ve kimyasal özellikleri üzerine olan etkileri. Ege Üniversitesi Ziraat Fakültesi Dergisi, 43(2): 109120.

Lehmann, J., Joseph, S.(Eds.), 2015. Biochar for environmental management: Science, Technology and İmplementation. 22s, Routledge.

Liu, X.H., Han, F.P., Zhang, X.C., 2012. Effect of biochar on soil aggregates in the loess plateau: results from incubation experiments. International Journal of Agriculture and Biology 14(6): 975- 979.

Mankasingh, U., Choi, P.C., Ragnarsdottir,V., 2011. Biochar application in a tropical, agricultural region: a plot scale study inTamil Nadu, India. Applied Geochemistry, 26: 218-221. doi.org/10.1016/j.apge ochem.2011.03.108.

Mauromicale, G., Marchese, M., Restuccia, A., Sapienza, O., Restuccia, G., Longo, A.M.G., 2005. Root nodulation and nitrogen accumulation and partitioning in legume crops as affected by soil 
solarization. Plant and soil, 271(1-2): 275-284. doi.org/10.1007/s11104-004-2772-0.

Mujdeci, M., Isildar, A.A., Uygur, V., Alaboz, P., Unlu, H., Senol, H., 2017. Cooperative effects of field traffic and organic matter treatments on some compaction-related soil properties. Solid Earth, 8(1): 189-198. doi.org/10.5194/se-8-189-2017.

Negiş, H., Şeker, C., Gümüş, I., Manirakiza, N., Mücevher, O., 2019. Effects of biochar and compost applications on penetration resistance and physical quality of a sandy clay loam soil. Communications in Soil Science and Plant Analysis, 51(1): doi.org/38-44. 10.1080/00103624.2019.1695819.

Novak, J.M., Busscher, W.J., Watts, D.W.,Amonette, J.E., Ippolito, J.A., Lima, I.M., Gaskin, J., Das, K.C., Steiner, C., Ahmedna, M., 2012. Biochars impact on soil moisture storage in an ultisol and two aridisols. Soil Science, 177: 310-320. doi.org/10.1097/SS.0b013e31824e5593.

Öz, H., Coşkan, A., Atılgan, A., 2016. Effect of different plastic cover materials and biofumigation to soil organic matter decomposition in greenhouse solarization. Scientific Papers. Series A. Agronomy, Vol. LIX, 2016: 127-130.

Öz, H., Coşkan, A., Atılgan, A., 2017. Determination of effects of various plastic covers and biofumigation on soil temperature and soil nitrogen form in greenhouse solarization -new solarization cover material- Journal of Polymers and The Environment, Springer, 25(2): 370-377.

Öz, H., 2018. A new approach to soil solarization: addition of biochar to the effect of soil temperature and quality and yield parameters of lettuce (Lactuca Sativa L. Duna). Scientia Horticulturae, 228: 153161. doi.org/10.1016/j.scienta.2017.10.021.

Patel, R. H., Shroff, J., Dutta, S., Meisheri, T. G., 2005. Weed dynamics as influenced by soil solarization-A review. Agricultural Reviews, 26(4): 295-300.

Raj, H., Bhardwaj, M.L., 2000. Soil solarization for controlling soil-borne pathogens in vegetable crops. Indian Journal of Agricultural Sciences, 70 (5): 305307.

Reddy, P.P., 2011. Biofumigation and Solarization for Management of Soil-Borne Plant Pathogens. Scientific Publishers.

Sağlam, T., Cangir, M., Bahtiyar, C., Tok, M., 1993. Toprak Bilimi, Trakya Üniversitesi, Tekirdağ Ziraat Fakültesi, Toprak Bölümü. Tekirdağ.

Scopa, A., Dumontet, S., 2007. Soil solarization: effects on soil microbiological parameters. Journal of plant nutrition, 30(4): 537-547. doi.org/10.1080/01904 160701209212.

Seman-Varner, R., McSorley, R., Gallaher, R.N., 2008. Soil nutrient and plant responses to solarization in an agroecosystem utilizing an organic nutrient source. Renewable agriculture and food systems, 23(2): 149154. doi.org/10.1017/S1742170507002001.
Silva, W.M.D., Bianchini, A., Cunha, C.A.D., 2016. Modeling and correction of soil penetration resistance for variations in soil moisture and soil bulk density. Engenharia Agrícola, 36(3): 449-459. doi.org/10.1590/1809-4430-Eng. Agric.v36n3p449459/2016.

Sofi, T. A., Tewari, A. K., Razdan, V. K., Koul, V.K., 2014. Long term effect of soil solarization on soil properties and cauliflower vigor. Phytoparasitica, 42(1): 1-11. doi.10.1007/s12600-013-0331-z.

Soil Survey Laboratory Staff, 1992. Soil survey laboratory methods manual, Soil Survey Investigations Report No.42. USDA-SCS, National Soil Survey Center, Lincoln, NE .

Sun, F., Lu, S., 2014. Biochars improve aggregate stability, water retention, and pore space properties of clayey soil. Journal of Plant Nutrition and Soil Science 177(1): 26-33. doi.org/10.1002/jpln.2012 00639.

Şeker, C., Işıldar, A.A., 2000. Tarla trafiğginin toprak profilindeki gözenekliliğe ve sıkışmaya etkisi. Turkish Journal of Agriculture and Forestry, 24: 7177.

U.S Salinity Laboratory Staff., 1954. Diagnosis and Improvement of Salina and Alkali Soils. Agricultural Handbook, 60, U.S.D.A.

Verheijen, F., Jeffery, S., Bastos, A. C., Van der Velde, M., Diafas, I., 2010. Biochar application to soils. A critical scientific review of effects on soil properties, processes, and functions. EUR, 24099: 162.

Yılmaz, E., Alagöz, Z., 2000. Farklı kökenli organik materyallerin toprakta agregat oluşumu ve stabilitesi üzerine etkileri. Akdeniz Üniversitesi Ziraat Fakültesi Dergisi, 13(2): 223-229. 